\title{
Systemic Magnesium Deficiency Disclosed by Magnesium Loading Test in Patients with Essential Hypertension
}

\begin{abstract}
Ryoji Ozono, Tetsuya Oshima*, Hideo Matsuura, Yukihito Higashi, Takafumi Ishida, Mitsuaki Watanabe, Mitsuisa Yoshimura, Hiroyuki Hiraga, Norihisa Ono, and Goro Kajiyama

The present study was designed to determine whether magnesium $(\mathrm{Mg})$ deficiency is present in patients with essential hypertension. We measured the retention of an intravenously administered $\mathrm{Mg}$ load $(0.2$ mmol/kg $\mathrm{MgSO}_{4}$ over $4 \mathrm{~h}$ ), and serum and erythrocyte $\mathrm{Mg}$ concentrations in 17 inpatients with essential hypertension and in 15 normotensive controls. There was no significant difference between the two groups in erythrocyte Mg concentration (normotensives vs., hypertensives: $2.0 \pm 0.5$ vs. $2.1 \pm 0.4$ $\mathrm{mmol} / \mathrm{l}$ cells), serum Mg concentration (normotensives vs. hypertensives: $2.1 \pm 0.2 \mathrm{vs} .2 .1 \pm 0.2 \mathrm{mg} / \mathrm{dl}$ ), or in urinary $\mathrm{Mg}$ excretion (normotensives vs. hypertensives: $65.8 \pm 25.5$ vs. $73.7 \pm 26.7 \mathrm{mg} / \mathrm{day}$ ). However, Mg retention was significantly higher in hypertensives than in normotensives (normotensives vs. hypertensives: $31.8 \pm 12.1$ vs. $41.9 \pm 13.3 \%$ ). These results suggest that a systemic $\mathrm{Mg}$ deficiency, which is undetectable by serum or erythrocyte Mg determination, may exist in patients with essential hypertension. (Hypertens Res 1995; 18: 39-42)
\end{abstract}

Key Words: magnesium, essential hypertension, magnesium retention

Although numerous pathophysiological abnormalities have been described, the underlying mechanisms of essential hypertension remain unknown. Magnesium (Mg) is essential to many cell functions (1), including transmembrane $\mathrm{Ca}^{2+}$ flux and plasma membrane $\mathrm{Na}^{+}-\mathrm{K}^{+}$ATPase activation. Experimental studies have demonstrated that hypomagnesemia caused vasoconstriction (2), and Mg-deficient rats developed systemic hypertension (3). These observations indicate that $\mathrm{Mg}$ deficiency may be an important contributory factor to the development of hypertension. In support of this hypothesis, several investigators have demonstrated an inverse correlation between blood pressure and serum $\mathrm{Mg}(4)$ or intracellular free $\mathrm{Mg}$ concentration $(5)$, and others $(6,7)$ have shown a blood pressure lowering effect of oral $\mathrm{Mg}$ supplementation. However, conflicting results have been also reported $(8$, $9)$, and recent clinical trials $(10,11)$ of oral $\mathrm{Mg}$ treatment in patients with essential hypertension failed to show any effect of $\mathrm{Mg}$ on blood pressure. Thus, whether or not $\mathrm{Mg}$ deficiency, either at the cellular or systemic level, is involved in the onset and maintenance of essential hypertension still remains controversial.

To study the role of $\mathrm{Mg}$ in the pathogenesis of essential hypertension, intracellular free $\mathrm{Mg}$ concentration in vascular smooth muscle should be examined (12). Since specimens of vascular smooth muscle cannot be readily obtained from humans, total $\mathrm{Mg}$ concentrations in blood cells, including lymphocytes $(1,13)$ and erythrocytes $(1,4,9,14)$, have been widely used and are considered to reflect the intracellular $\mathrm{Mg}$ status. Serum $\mathrm{Mg}$ concentration (15) and 24-h urinary $\mathrm{Mg}$ excretion $(1,9)$ may provide the bases for estimating systemic $\mathrm{Mg}$ balance, but extracellular fluid contains only $1 \%$ of total body $\mathrm{Mg}$ and urinary $\mathrm{Mg}$ excretion is largely affected by $\mathrm{Mg}$ intake. The best estimate of $\mathrm{Mg}$ status in man is thus debatable.

The retention of intravenously loaded $\mathrm{Mg}$, calculated using urinary $\mathrm{Mg}$ excretion before and after $\mathrm{Mg}$ loading, has been demonstrated to inversely correlate with total body $\mathrm{Mg}(16,17)$, and this $\mathrm{Mg}$ retention is considered to be one of the most reliable indices of systemic $\mathrm{Mg}$ deficiency. Increased $\mathrm{Mg}$ retention has been reported in patients with congestive heart failure (18), myocardial infarction (19) and variant angina pectoris (20), as well as in patients with chronic alcoholism $(21,22)$ who had extreme $\mathrm{Mg}$ deficiency. Furthermore, repletion of $\mathrm{Mg}$ resulted in a reduction in the $\mathrm{Mg}$ retention (18,

From the First Department of Internal Medicine and * Department of Clinical Laboratory Medicine, Hiroshima University School of Medicine, Japan.

This study was supported in part by a Grant-in-Aid for Scientific Research (no.02670396 and 06672293) from the Ministry of Education, Science and Culture, Japan and from the Kurozumi Medical Foundation.

Address for Reprints: Tetsuya Oshima, M.D., Department of Clinical Laboratory Medicine, Hiroshima University School of Medicine, 1-2-3 Kasumi, Minami-ku, Hiroshima 734, Japan.

Received April 16, 1994; accepted in revised form August 4, 1994. 
21) accompanied by an improvement in clinical manifestations of $\mathrm{Mg}$ deficiency (21). To date, however, $\mathrm{Mg}$ retention has not been studied in untreated patients with essential hypertension.

In the present study, we compared systemic and intracellular $\mathrm{Mg}$ status between essential hypertensives and normotensive controls by the $\mathrm{Mg}$ loading test and by measuring $\mathrm{Mg}$ concentrations in serum and erythrocytes.

\section{Subjects and Methods}

Seventeen patients with mild to moderate essential hypertension ( 7 men and 10 women, mean age $55.7 \pm 12.6$ years) and 15 normotensve control subjects ( 7 men and 8 women, mean age $52.3 \pm 16.8$ years) were studied. Hypertension was defined as a diastolic blood pressure more than $90 \mathrm{mmHg}$ in the sitting position on at least three different occasions in the outpatient clinic. Patients with severe organ damage and secondary forms of hypertension were excluded. Three of the 17 subjects had never received antihypertensive drugs. For the others, all antihypertensive medication was discontinued for at least 3 weeks before the study. Among the 14 patients who were receiving antihypertensive therapy, 10 were prescribed calcium channel blockers, $3 \beta$-blockers, and 1 both a calcium channel blocker and an angiotensin converting enzyme inhibitor. None had received any diuretics for a year before the study. Normotensive controls were enrolled from subjects with atypical chest pain in whom no evidence of diseases was detected by coronary angiography, thallium-201 myocardial scintigraphy, and echocardiography. All the normotensive controls had blood pressure less than 140/90 $\mathrm{mmHg}$ and received no medication. There was no significant difference between the two groups in mean body weight (normotensives $v s$. hypertensives: $57.9 \pm 9.0$ vs. $62.2 \pm 9.0 \mathrm{~kg}$ ), and or mean serum creatinine concentration $(0.80 \pm 0.23$ vs. $0.78 \pm 0.18 \mathrm{mg} / \mathrm{dl})$. Informed consent was obtained from all subjects.

All subjects were admitted to the Hospital of Hiroshima University School of Medicine (Hiroshima, Japan) and placed on a regular hospital diet containing $170 \mathrm{mEq} /$ day of sodium chloride. Baseline 24-h urine samples were collected for determination of $\mathrm{Mg}$ and creatinine excretion for 3-7 days after admission, and mean values for the last three days were used for analysis. Urine collection was started at 9:00 AM. On the morning of the $\mathrm{Mg}$ loading test, the subjects, who had fasted overnight, remained supine for $30 \mathrm{~min}$ after voiding, and blood pressure was measured 5 times at 1-min intervals with a mercury sphygmomanometer, and the mean value was used for analysis. Venous blood was drawn for determination of serum and erythrocyte total $\mathrm{Mg}$ concentrations and plasma renin activity. Subsequently, subjects received an intravenous dose of $\mathrm{MgSO}_{4}(0.2 \mathrm{mmol} / \mathrm{kg}$ body weight $)$ in 250 $\mathrm{ml}$ of 5\% dextrose in water at 9:00 AM over $4 \mathrm{~h}$. Serum $\mathrm{Mg}$ concentration was again determined at the end of $\mathrm{Mg}$ infusion. Twenty-four-hour urine samples were again collected, starting from the time of initiating the infusion, for determination of 24-h urinary excretion of $\mathrm{Mg}$ and creatinine. The baseline 24-h urinary $\mathrm{Mg}$ excretion was subtracted from postinfusion 24-h urinary $\mathrm{Mg}$ excretion. The ratio of the difference in urinary $\mathrm{Mg}$ excretion to the total amount of $\mathrm{Mg}$ infused was expressed as a percent of loaded $\mathrm{Mg}$ retention at $24 \mathrm{~h}$ after infusion. Thus, $\mathrm{Mg}$ retention (\%) was calculated according to the following equation: \{total amount of $\mathrm{Mg}$ infused - (post infusion 24-h urinary $\mathrm{Mg}-$ baseline 24 -h urinary $\mathrm{Mg}$ ) $\} \times 100 /$ total amount of $\mathrm{Mg}$ infused.

A preliminary study revealed that the coefficient of variance of baseline 24-h urinary $\mathrm{Mg}$ excretion within one hospitalized individual was $36 \pm 15.0 \%$ (average of 13 subjects). Based on these findings, the postinfusion 24-h urinary Mg excretion was corrected for baseline-related variations in baseline $\mathrm{Mg}$ excretion.

Serum $\mathrm{Mg}$, urine $\mathrm{Mg}$ and urine creatinine concentrations were determined by auto-analyzer. Erythrocyte $\mathrm{Mg}$ was calculated as previously described (23) from the $\mathrm{Mg}$ concentration, measured by atomic absorption (Shimadzu, Kyoto, Japan) in hemolysates prepared from erythrocytes that had been washed three times with ice-cold isotonic cholinechloride solution, packed in a microcapillary tube (Hematolon, Kayagaki Irikakogyo, Kumamoto, Japan), and centrifuged at $15,000 \mathrm{~g}$ for $5 \mathrm{~min}$. Plasma renin activity was measured by radioimmunoassay (Gamma Coat PRA, Baxter Travenol Ltd, Tokyo, Japan) as previously described (23).

All data were expressed as mean \pm SD. Student's unpaired $t$-test and simple regression analysis were used for statistical analysis. A $p$ value $<0.05$ was accepted as significant.

\section{Results}

Systolic and diastolic blood pressure were 122.8 \pm 19.7 and $75.9 \pm 7.0 \mathrm{mmHg}$ in normotensives, and $152.6 \pm 21.7$ and $92.4 \pm 9.7 \mathrm{mmHg}$ in hypertensives, respectively. As shown in Table 1 , there was no significant difference in baseline 24-h urinary excretions of $\mathrm{Mg}$ and creatinine, serum $\mathrm{Mg}$ concentration, erythrocyte $\mathrm{Mg}$ concentration, plasma renin activity or creatinine clearance between the normotensives and hypertensives. Twenty-fourhour urinary creatinine excretion was similar preinfusion and postinfusion in each group.

$\mathrm{Mg}$ infusion resulted in a significant $(p<0.01)$ elevation in serum $\mathrm{Mg}$ concentration both in normotensives and hypertensives, and there was no significant difference in the postinfusion serum $\mathrm{Mg}$ concentration between the two groups (normotensives vs. hypertensives: $3.4 \pm 0.2$ vs. $3.5 \pm 0.4$ $\mathrm{mg} / \mathrm{dl}$ ). However, the hypertensives retained a significantly greater amount of $\mathrm{Mg}$ than did the normotensives (normotensives vs. hypertensives: 31.8 \pm 12.1 vs. $41.9 \pm 13.3 \%, p<0.05$, Fig. 1) although there was a relatively wide overlap between the groups. Furthermore, in the combined group, the $\mathrm{Mg}$ retention was significantly and positively correlated with mean blood pressure $(r=$ 
Table 1. Variables in Normotensive and Hypertensive Subjects

\begin{tabular}{llcc}
\hline & & Normotensives & Hypertensives \\
\hline Systolic blood pressure & $(\mathrm{mmHg})$ & $122.8 \pm 19.7$ & $152.6 \pm 21.7^{*}$ \\
Diastolic blood pressure & $(\mathrm{mmHg})$ & $75.9 \pm 7.0$ & $92.4 \pm 9.7^{*}$ \\
Preinfusion serum $\mathrm{Mg}$ & $(\mathrm{mg} / \mathrm{dl})$ & $2.1 \pm 0.2$ & $2.1 \pm 0.2$ \\
Postinfusion serum $\mathrm{Mg}$ & $(\mathrm{mg} / \mathrm{dl})$ & $3.4 \pm 0.2$ & $3.5 \pm 0.4$ \\
Erythrocyte Mg & $(\mathrm{mmol} / \mathrm{l}$ cells $)$ & $2.1 \pm 0.4$ & $2.0 \pm 0.5$ \\
Preinfusion 24-h urinary Mg & $(\mathrm{mg} / \mathrm{day})$ & $65.8 \pm 25.5$ & $73.7 \pm 26.7$ \\
Postinfusion 24-h urinary $\mathrm{Mg}$ & $(\mathrm{mg} / \mathrm{day})$ & $243.2 \pm 35.0$ & $254.1 \pm 38.9$ \\
Preinfusion 24-h urinary Cr & $(\mathrm{mg} / \mathrm{day})$ & $1,079 \pm 175$ & $1,045 \pm 217$ \\
Postinfusion 24-h urinary Cr & $(\mathrm{mg} / \mathrm{day})$ & $1,082 \pm 113$ & $1,053 \pm 175$ \\
Plasma renin activity & $(\mathrm{ng} \mathrm{AI} / \mathrm{ml} / \mathrm{h})$ & $1.6 \pm 1.9$ & $1.7 \pm 2.4$ \\
Cr clearance & $(\mathrm{ml} / \mathrm{min})$ & $92.6 \pm 20.5$ & $95.0 \pm 15.3$ \\
\hline$*$ * & & &
\end{tabular}

vs, normotensives

$\mathrm{Cr}$, creatinine.

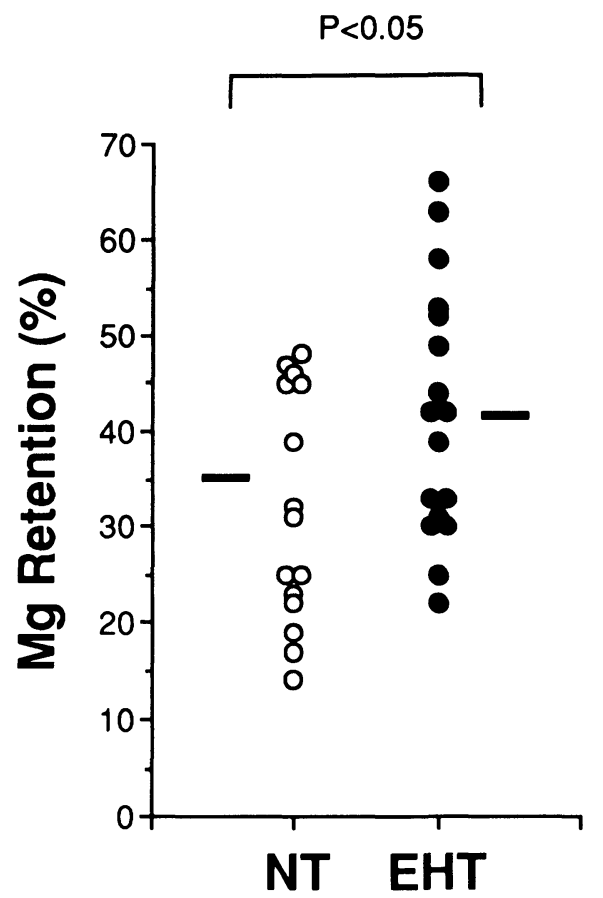

Fig. 1 Magnesium retention in normotensive subjects (NT) and essential hypertensive patients (EHT).

$0.35, p<0.05)$. In the combined group, the $\mathrm{Mg}$ retention had no significant correlation with age $(r=$ $-0.29)$, serum creatinine concentration $(r=0.01)$, serum $\mathrm{Mg}$ concentration $(r=-0.23)$, erythrocyte $\mathrm{Mg}$ concentration $(r=-0.16)$, or with plasma renin activity $(r=0.07)$. In addition, no difference in the $\mathrm{Mg}$ retention was detected between men and women in the combined group (men vs. women: $36.8 \pm 12.6 v s .37 .4 \pm 14.6 \%$ ) or in each group.

\section{Discussion}

In the present study, we demonstrated that essential hypertensive patients retained a larger proportion of loaded $\mathrm{Mg}$ than did normotensive subjects, indicating the presence of systemic $\mathrm{Mg}$ deficiency in essential hypertensive patients. However, we could detect no significant difference in serum $\mathrm{Mg}$ concentration, erythrocyte $\mathrm{Mg}$ concentration, or in 24-h urinary $\mathrm{Mg}$ excretion between the normotensive and hypertensive subjects.

Although the difference was statistically significant, there was a substantial overlap in the $\mathrm{Mg}$ retention between the hypertensive and normotensive subjects. Resnick et al. (5) have demonstrated a striking difference in intracellular free $\mathrm{Mg}$ level between "low-renin" essential hypertensive patients and control subjects but not between "high renin" patients and the control subjects. In the present study, the $\mathrm{Mg}$ retention in our hypertensive subjects was unrelated to plasma renin activity or other factors that may affect $\mathrm{Mg}$ retention, including age, sex, and renal function. The overlap between the two groups in the $\mathrm{Mg}$ retention suggests that the $\mathrm{Mg}$ deficiency alone does not account for the pathogenesis of essential hypertension, but it is one of the significant factors contributing to the elevation of blood pressure.

Since only $1 \%$ of total body $\mathrm{Mg}$ is in the extracellular space (1), serum $\mathrm{Mg}$ concentration may not accurately reflect total body $\mathrm{Mg}$. Previous studies $(1,5,9,24)$ also have failed to find a difference in serum levels of $\mathrm{Mg}$ between hypertensive and control subjects. Hypomagnesemia is observed only when the $\mathrm{Mg}$ deficiency is severe $(18,21,22)$. It is likely that the $\mathrm{Mg}$ deficiency in our hypertensive subjects was not severe enough to affect the serum Mg level.

Although the $\mathrm{Mg}$ retention was greater in the hypertensive subjects showing a systemic $\mathrm{Mg}$ deficiency, we could not detect a decrease in erythrocyte total $\mathrm{Mg}$ concentration in the hypertensives. Although this erythrocyte $\mathrm{Mg}$ concentration is widely used as an index for intracellular $\mathrm{Mg}$ status $(1,4$, 9 , 14), there is no convincing evidence that it reflects intracellular $\mathrm{Mg}$ levels in other cells such as vascular smooth muscle cells. In addition, the intracellular free $\mathrm{Mg}$ account for only approximately $10 \%$ of total $\mathrm{Mg}$ content $(4,5,8)$. We cannot discard the possibility that total $\mathrm{Mg}$ concentration in erythrocytes may not be a suitable index to detect 
differences in cellular $\mathrm{Mg}$ status between hypertensive and normotensive subjects.

Previously, $\mathrm{Mg}$ deficiency in patients with cardiovascular diseases such as vasospastic angina (20), myocardial infarction (19), arrhythmia (18) and congestive heart failure (18) was detected using the $\mathrm{Mg}$ loading test. Gullestad et al. (18) reported that patients with essential hypertension had increased $\mathrm{Mg}$ retention, but most of the patients in those studies were on diuretic treatment, established as the most common cause of systemic $\mathrm{Mg}$ deficiency (1). Our study is the first to demonstrate an increased Mg retention in patients with untreated essential hypertension.

If systemic $\mathrm{Mg}$ deficiency exists, urinary $\mathrm{Mg}$ excretion may be decreased. However, we could not find any difference in urinary $\mathrm{Mg}$ excretion between the groups. The coefficient of variance of the 24-h urinary $\mathrm{Mg}$ excretion was $36 \%$ in one subject, since it is difficult to control the $\mathrm{Mg}$ intake. Thus, such relatively large day-to-day variations may mask small group differences in basal urinary $\mathrm{Mg}$ excretion.

In summary, we demonstrated that the Mg loading test disclosed a systemic $\mathrm{Mg}$ deficiency in patients with essential hypertension. This deficiency was not detected based on serum and intraerythrocyte concentrations of $\mathrm{Mg}$ or 24-h urinary $\mathrm{Mg}$ excretion. Our data support the hypothesis that systemic $\mathrm{Mg}$ deficiency plays a role in the pathogenesis of essential hypertension.

\section{References}

1. Reinhart RA: Magnesium metabolism: a review with special reference to the relationship between intracellular content and serum levels. Arch Intern Med 1988; 148: 2415-2420.

2. Altura BM, Altura BT, Carella A: Magnesium deficiency-induced spasm of umbilical vessels: relation to preeclampsia, hypertension, growth retardation. Science 1983; 221: 376-378.

3. Altura BM, Altura BT, Gebrewold A, Ising $\mathbf{H}$, Gunther T: Magnesium deficiency and hypertension: correlation between magnesium-deficient diets and microcirculatory changes in situ. Science 1984; 223:1315-1317.

4. Petersen B, Schroll M, Christiansen C, Transbøl I: Serum and erythrocyte magnesium in normal elderly Danish people. Acta Med Scand 1977; 201: 31-34.

5. Resnick LM, Gupta RK, Laragh JH: Intracellular free magnesium in erythrocytes of essential hypertension: relation to blood pressure and serum divalent cations. Proc Natl Acad Sci USA 1984; 81: 6511-6515.

6. Motoyama T, Sano H, Fukuzaki H: Oral magnesium supplementation in patients with essential hypertension. Hypertension 1989; 13: 227-232.

7. Dickner T, Wester PO: Effect of magnesium on blood pressure. Br Med J 1983; 286: 1847-1849.

8. Woods KL, Walmsley D, Heagety AM, Turner DL, Lian $L Y:{ }^{3} \mathrm{P}$ nuclear magnetic resonance measurement of free erythrocyte magnesium concentration in man and its relation to blood pressure. Clin Sci 1988; 74: $513-517$

9. Kjeldsen SE, Sejersted OM, Frederichsen P, Leren $P$, Edie IK: Increased erythrocyte magnesium content in essential hypertension. Scand J Clin Lab Invest 1990; 50: 395-400.

10. Cappuccio FP, Markandu ND, Beynon GW, Shore AC, Sampson B, MacGregor GA: Lack of effect of oral magnesium on blood pressure: a double blind study. Br Med J, 1985; 291: 235-238.

11. The trials of Hypertension Prevention Collaborative Research group: The effects of nonpharmacologic interventions on blood pressure of persons with high normal levels. JAMA 1992; 267:1213-1220.

12. Ng LL, Davies JE, Ameen M: Intracellular free-magnesium levels in vascular smooth muscle and striated muscle cells of the spontaneously hypertensive rat. Metabolism 1992; 41: 772-777.

13. Wong NLM, Sutton RAL, Dirks JH: Is lymphocyte magnesium concentration a reflection of intracellular magnesium concentration? J Lab Clin Med 1988; 112: 721-726.

14. Touyz RM, Milne FJ, Reinach SG: Platelet and erythrocyte $\mathrm{Mg}^{2+}, \mathrm{Ca}^{2+}, \mathrm{Na}^{+}, \mathrm{K}^{+}$and cell membrane adenosine triphosphatase activity in essential hypertension in blacks. J Hypertens 1992; 10: 571-578.

15. Whang R, Oei TO, Aikawa JK, et al: Predictors of clinical hypomagnesemia. Hypokalemia, hypophosphatemia, hyponatremia, and hypocalcemia. Arch Intern Med 1984; 144: 1794-1796.

16. Jones JE, Shane SR, Jacobs WH, Flink BF: Mg balance studies in chronic alcoholism. Ann N Y Acad Sci 1969; 162: 934-945.

17. Caddel JL, Reed GF: Validity of the parenteral magnesium load test for mature mammals. Magnesium 1989; 8: $65-70$.

18. Gullestad L, Dolva L $\varnothing$, Waage A, Falch D, Fagerthun $\mathrm{H}$, Kjekshus J: Magnesium deficiency diagnosed by an intravenous loading test. Scand J Clin Lab Invest 1992; 52: 245-253

19. Rasmussen HS, McNir P, Gøransson L, Balsløv S, Larsen OG, Auruo P: Magnesium deficiency in patients with ischemic heart disease with and without acute myocardial infarction uncovered by an intravenous loading test. Arch Intern Med 1988; 148: 329-332.

20. Goto K, Yasue H, Okumura K, et al: Magnesium deficiency detected by intravenous loading test in variant angina pectoris. Am J Cardiol 1990; 65: 709712.

21. Ryzen E, Elbaum N, Singer FR, Rude R: Parenteral magnesium tolerance testing in the evaluation of magnesium deficiency. Magnesium 1985; 4: 137-147.

22. Bøhmer T, Mathiesen B: magnesium deficiency in chronic alcoholic patients uncovered by intravenous loading test. Scand J Clin Lab Invest 1982; 42: 633-636.

23. Oshima $\mathrm{T}$, Matsuura $\mathrm{H}$, Ishibashi $\mathrm{K}$, et al: Familial influence upon $\mathrm{NaCl}$ sensitivity in patients with essential hypertension. J Hypertens 1992; 10: 10891094.

24. Handwerker SM, Altura BT, Royo B, Altura BM: Ionized magnesium and calcium levels in umbilical cord serum of pregnant women with transient hypertension during labor. $A m J$ Hypertens 1993; 6: 542-545. 